\title{
Internalisasi Pendidikan Pasar Modal pada Mahasiswa Jurusan Akuntansi dalam Rangka Optimalisasi Life Laboratory Program Studi Analis Keuangan
}

\author{
Sri Widiyati ${ }^{1 *}$, Manarotul Fatati ${ }^{2}$, Th. Tyas Listyani ${ }^{3}$ \\ 1,2,3 Jurusan Akuntansi, Politeknik Negeri Semarang \\ *wiwidsoemodipoero@yahoo.co.id
}

\begin{abstract}
The existence of Life Laboratory (The Capital Market Gallery of BEI) has not given much benefit to Accounting Department. and Polines. For that reason, the acceptance of Life Laboratory's capacity by internalizing Capital Market to students must be done. The purpose of the research is to know the respondent's perception of investment in Capital Market, to know the level of literacy, to know the correlation of literacy level with demographic variables and capitalization design of Capital Market Education on Polines students. The majority of respondents' perceptions of investments in the capital market industry are positive. The level of literacy of respondents is approached with the level of knowledge about the institutional Capital Market, Capital Market products and Securities Trading. In general the level of respondents knowledge about the Capital Market is low - moderate. The research results show that there is no correlation between gender, the origin of the respondent, the level of expenditure with the level of capital market literacy. While the origin of courses and semesters associated with the level of literacy Capital Market. The capital market internalization model begins with the Capital Market school and the following stages are stocks. In the early days, new investor assistance is needed until adult investors (able to transact on their own).
\end{abstract}

Keywords: life laboratory, capital market, literacy

\begin{abstract}
Abstrak
Eksistensi Life Laboratory(Galeri Pasar Modal BEI) belum memberikan banyak kemanfaatan pada Jurusan Akuntansi dan Polines .Untuk itulah pengoptimaalan kapasitas Life Laboratory dengan menginternalisasi Pasar Modal pada mahasiswa harus segera dilakukan.Tujuan penelitian ada untuk mengetahui persepsi responden terhadap investasi pada Pasar Modal,mengetahui tingkat literasi, untuk mengetahui korelasi tingkat literasi dengan variabel demografi dan rancangan modal internalisasi Pendidikan Pasar Modal pada mahasiswa Polines. Mayoritas persepsi responden terhadap investasi pada industri Pasar Modal adalah positip.Tingkat literasi responden didekati dengan tingkat pemahaman pengetahuan tentang kelembagaan Pasar Modal, produk Pasar Modal dan Perdagangan Efek.Secara umum tingkat pengetahuan responden terhadap Pasar Modal adalah rendah - sedang.Hasil penelitian memperlihatkan bahwa tidak ada korelasi antara gender, asal responden, tingkat pengeluaran dengan tingkat literasi Pasar Modal.Sedangkan asal program studi dan semester berkaitan dengan tingkat literasi Pasar Modal.Model internalisasi Pasar Modal dimulai dengan sekolah Pasar Modal dan tahapan berikut adalah nabung saham. Pada masa awal diperlukan pendampingan investor baru sampai investor dewasa (mampu bertransaksi sendiri).
\end{abstract}

Kata kunci: life laboratory, pasar modal, literasi

\section{Pendahuluan}

\subsection{Sub Judul}

Berdasarkan Survey Nasional Literasi dan Inklusi Keuangan 2016 yang dilakukan oleh OJK (http://www.ojk.go.id), tingkat inklusi pada industri pasar modal paling rendah yaitu 1,25 \%.Hal ini dikarenakan masyarakat mempersepsikan investasi di pasar modal membutuhkan dana yang besar, utilitas produk pasar modal masih relatip jauh dibanding produk industri keuangan 
lainnya dan investasi pada pasar modal seperti bermain judi (http://www.antaranews.com). Situasi tersebut mengambarkan bahwa tingkat literasi Pasar Modal relatif rendah.

Menurut Remund (2010), definisi operasional literasi keuangan adalah pemilikan pengetahuan, ketrampilan serta rasa percaya untuk mengambil keputusan keuangan yang bertanggung jawab. Dengan demikian pengetahuan tentang keuangan tidak cukup untuk pengambilan keputusan keuangan tetapi masih dibutuhkan ketrampilan dan rasa percaya diri. Sedangkan Kamal Gupta dan Jatinder Kaur (2014) memberikan pengertian Financial Literacy (literasi keuangan) merupakan kombinasi kesadaran keuangan, pengetahuan, keterampilan,sikap serta perilaku yang diperlukan dalam pengambilan keputusan keuangan yang benar dan akan memberikan kesejahteraan individu. Literasi keuangan akan memberikan pengetahuan yang berkaitan dengan risk dan return terhadap penggunaan produk-produk keuangan serta lembaga keuangan (Bonte, 2012).

Rendahnya inklusi pasar modal di Indonesia, maka Bursa Efek Indonesia (BEI) gencar melakukan edukasi dan sosialisasi antara lain dengan Perguruan Tinggi dan civitas Akademika melalui pembentukan Galeri Investasi BEI yang merupakan kerjasama antara BEI, Perguruan Tinggi dan Perusahaan Sekuritas anggota BEI. Galeri investasi BEI diperguruan tinggi merupakan salah satu sarana edukasi dan laboratorium untuk mempelajari cara berinvestasi. Mahasiswa sebagai agen perubahan oleh OJK dianggap calon investor potensial sehingga menjadi target peningkatan inklusi keuangan khususnya pasar modal.

Menurut Lusardi A. dan Mitchell (2011), ada empat prinsip yang perlu diperhatikan dalam rangka mengukur tingkat literasi keuangan.Empat prinsip tersebut adalah simplicity, relevance, brevity and capacity to differentiate. Indikator yang digunakan untuk mengukur tingkat literasi keuangan adalah pengetahuan tentang bunga berbunga, pengetahuan tentang inflasi dan pengetahuan tentang diversifikasi resiko. Sedangkan indikator yang digunakan OECD dalam mengukur tingkat literasi konsumen adalah Financial Knowledge, Financial Behavior and Financial Attitudes (Atkinson and Messy, 2012).

Lusardi dan Mitchell (2011), tingkat literasi keuangan sering dikaitkan dengan variabel demografi dan variabel social ekonomi. Tingkat literasi keuangan diukur dengan sejauh mana pemahaman terhadap tingkat bunga, inflasi dan risk-return. Hasil penelitian memperlihatkan bahwa generasi muda, pengangguran, pendapatan rendah berkorelasi dengan tingkat literasi keuangan yang rendah.

Penelitian yang dilakukan Anna Maria Lusardi,Olivia S, Mitchell dan Vilsa Curto (2010), mengkaitkan literasi keuangan dengan variabel sosial-demografi dan keuangan keluarga. Responden adalah generasi muda. Hasil penelitian memperlihatkan bahwa keuangan berkorelasi positif dengan variabel social-demografi dan keuangan keluarga. Hasil studi menunjukan bahwa mahasiswi yang orang tuanya memiliki saham dan tabungan hari tua lebih memahami diversifikasi resiko dibanding pelajar yang orang tuanya tidak memiliki kekayaan. Sementara kelihaian A dan Williams A melakukan studi pada mahasiswa akuntansi. Penelitian yang dilakukan mengkaitkan bekal ilmu keuangan yang diperoleh dengan tingkat literasi. Hasil penelitian menunjukan bahwa bekal ilmu keuangan tidak berpengaruh signifikan terhadap tingkat literasi keuangan. Untuk itu perlu evaluasi mata kuliah manajemen keuangan.

Penelitian pada generasi muda di Australia yang dilakukan oleh Samy M., Taufik H., Huang R., dan Nagar A.K. (2012) berkaitan dengan kartu kredit, pinjaman dan superannuation. Hasil penelitian menunjukan bahwa lama studi, status kartu kredit maupun kebiasan sehari-hari memiliki relevansi dengan pengetahuan responden tentang kartu kredit. Hasil penelitian Tian Xia, Zhengwei Wang dan Kunpeng Li (2011) memperlihatkan bahwa financial literacy overconfidence berkorelasi positif dengan tingkat partisipasi pada pasar modal dan under 
confidence berkorelasi negatif. Tipe tidak percaya diri akan menanggung kerugian jika berpartisipasi pada pasar modal.

Lewis Mandell dan Linda Schmid Klein (2009) melakukan studi dengan judul The Impact of Financial Literacy Education on Subsequent Financial Behavior.Penelitian dilakukan pada murid SLTA yang telah mengambil mata pelajaran personal financial management dan yang belum mengambil. Hasil penelitian memperlihatkan bahwa murid SLTA yang telah mendapat mata pelajaran personal financial management memiliki pengetahuan keuangan lebih tinggi. Meskipun demikian baik murid SLTA yang telah mengambil mata pelajaran personal financial management dan yang belum mendapat mata pelajaran personal financial management tidak ada orientasi untuk menabung dan sikap terhadap uang tidak menjadi lebih baik. Carlo de Basa Scheresberg (2013) menyimpulkan bahwa literasi keuangan yang rendah pada kelompok minoritas, wanita, dan juga mereka yang berpendapatan rendah dan pendidikan yang tinggi belum menjamin berbanding lurus dengan tingkat literasi keuangan.

Dari berbagai hasil penelitian di atas dapat disimpulkan bahwa tingkat literasi keuangan, mutu modal manusia maupun variabel sosial demografi akan berpengaruh pada parsipasi masyarakat pada lembaga keuangan. Di berbagai negara tingkat partisipasi dipengaruhi oleh peran lembaga dalam mensosialisasi , sistem pendidikan dan daya tarik lembaga keuangan di Negara yang bersangkutan.

Keberadaan Life Laboratory (Galeri Investasi BEI) di Polines sampai saat ini masih dikonsumsi hanya dua Program Studi yaitu Program Studi Analis Keuangan dan Program Studi Keuangan dan Perbankan yang memiliki mata kuliah Pasar Modal dalam kurikulumnya. Keberadaan Galeri Investasi BEI diharapkan mengakomodasi civitas akademika untuk berkiprah pada industry pasar modal.Untuk itulah pengoptimaalan kapasitas Life Laboratory dengan menginternalisasi Pasar Modal pada mahasiswa harus segera dilakukan sehingga permasalahan penelitian adalah: Bagaimana mengoptimalkan Life Laboratory (Galeri Investasi BEI) di Polines maka secara spefisik perumusan masalah yang ditetapkan dalam penelitian ini adalah: Bagaimana persepsi mahasiswa tentang Pasar Modal; Bagaimana korelasi antara variabel sosial demografi dengan tingkat literasi Pasar Modal pada mahasiswa; Bagaimana rancangan modal internalisasi Pendidikan Pasar Modal pada mahasiswa Polines.

\section{Metodologi}

Pengambilan sampel dilakukan secara purposive sampling yaitu teknik pengambilan sampel dengan pertimbangan khusus sehingga layak dijadikan sampel.Kriteria responden yang akan dijadikan sampel adalah mahasiswa Polines yang belum pernah belajar Pasar Modal secara formal di kampus. Pada penelitian ini sampel berasal dari program studi Akuntansi, program studi Akuntansi Manajerial dan Komputer Akuntansi dan Prodi Keuangan dan Perbankan.

Menurut Uma Sekaran (2006), ukuran sampel lebih dari 30 dan kurang dari 500 adalah tepat untuk kebanyakan penelitian. Untuk penelitian korelasional jumlah minimal sampel untuk memperoleh hasil yang baik adalah 30. Besar sampel yang diambil dalam penelitian ini adalah 50 responden.

Dalam penelitian ini data yang dibutuhkan data demografis dan social ekonomi responden (usia, pendidikan, jenis kelamin, pekerjaan orang tua, uang saku, pendidikan orang tua) serta data yang berkaitan dengan variabel yang diteliti. Metode pengumpulan data adalah sebagai berikut: Kuestioner, Pelatihan Pasar Modal, Observasi.

Kuestioner didesain dengan pernyataan dan atau pertanyaan terbuka dan tertutup. Kuestioner dibagi menjadi dua bagian. Bagian pertama berisikan pertanyaan menggali profil responden dilihat dari faktor demografis (jenis kelamin, pendidikan, uang saku, lama kuliah). Bagian kedua berisikan pernyataan/pertanyaan yang berkaitan dengan literasi keuangan. Jawaban 
telah disediakan dengan 5 alternatif jawaban dengan skala Likert (skala 1 jika jawaban sangat tidak setuju dan skala 5 adalah sangat setuju). Pelatihan Pasar Modal (untuk membedakan tingkat literasi sebelum dan sesudah pelatihan) dan observasi dilakukan untuk melihat dan mengamati secara langsung kondisi, dan kegiatan responden. Metode analisis data yang digunakan adalah analisis deskriptif, uji Chi Squared dan mengukur derajat keeratan hubungan tingkat literasi dengan variabel demografi.

\section{Hasil dan Pembahasan}

\subsection{Gambaran Umum Responden}

Responden adalah mahasiswa pada berbagai program studi pada Jurusan Akuntansi. $26 \%$ berasal dari Program Studi Akuntansi; $32 \%$ dari Program Studi Akuntansi Manajerial; $22 \%$ berasal dari Program Studi Keuangan dan Perbankan dan $20 \%$ berasal Program Studi Komputer Akuntansi. Dilihat dari jenis kelamin banyaknya responden laki-laki ada 14 orang (28\%) dan 36 orang adalah wanita. Dilihat dari asal responden sebagian besar responden berasal dari luar kota Semarang dan kebanyakan mereka berada pada semester lima. Tingkat pendidikan orang tua responden (ayah maupun ibu) adalah SMA dan pekerjaan orang tua responden sebagian wiraswasta.

\subsection{Persepsi Responden Terhadap Investasi Pasar Modal}

Persepsi merupakan suatu proses yang didahului oleh penginderaan, yaitu suatu stimulus yang diterima oleh individu melalui alat reseptor yaitu indera. Alat indera merupakan penghubung antara individu dengan dunia luarnya. Persepsi merupakan stimulus yang diindera oleh individu, diorganisasikan kemudian diinterpretasikan sehingga individu menyadari dan mengerti tentang apa yang diindera. Berkaitan dengan investasi pada Pasar Modal, persepsi responden dapat dilihat pada Tabel 1.

Tabel 1 Persepsi Responden Terhadap Investasi Pada Pasar Modal

\begin{tabular}{clcc}
\hline No. & Menurut anda investasi pada pasar modal : & Setuju & Tidak Setuju \\
\hline 1 & Hanya berlaku untuk orang kaya. & 13 & 37 \\
2 & Membutuhkan modal yang besar & 23 & 27 \\
3 & Berbelit-Belit & 18 & 32 \\
4 & Judi & 10 & 40 \\
5 & Produknya tidak jelas & 11 & 39 \\
6 & Membutuhkan waktu yang lama untuk menikmati & 25 & 25 \\
7 & hasil & & 12 \\
8 & Besiko Tinggi & 38 & 21 \\
9 & Kurang Menantang ilmu yang tinggi & 29 & 43 \\
10 & Nilai investasi cepat berubah & 7 & 30 \\
\hline
\end{tabular}

Sumber: Hasil Olah Data tahun 2017

Persepsi responden terhadap investasi pada industri Pasar Modal beragam responsenya. Lebih dari $50 \%$ responden memiliki persepsi bahwa investasi pada pasar modal dapat dilakukan semua orang dan bukan untuk orang kaya, tidak membutuhkan modal yang besar karena saat ini dengan Rp. 100.000,- orang sudah dapat deposit. Disamping itu responden telah memiliki persepsi bahwa investasi pada pasar modal tidak berbelit belit (terdapat sistem yang memudahkan investor bertransaksi); investasi di pasar modal bukan judi karena saat ini banyak saham Syariah yang juga ditawarkan pada BEI.

Dilihat dari produk, ternyata $78 \%$ responden tidak setuju kalau dikatakan produk pasar modal tidak jelas. Hal ini memperlihatkan bahwa responden mempunyai pengetahuan tentang 
produk pasar modal dimana saat ini bentuk pemilikan saham adalah paperless. Dilihat dari tingkat resiko investasi pada pasar modal adalah high risk.Pendapat tersebut didukung $76 \%$ responden. Diantara produk keuangan memang saham merupakan salah satu produk yang ditengari high risk tapi high income.

Tentang pemenuhan pengetahuan untuk investasi pada pasar modal, $58 \%$ responden setuju bahwa untuk investasi butuh pengetahuan. Pengetahuan yang dibutuhkan antara lain kinerja perusahaan serta kondisi di luar perusahaan yang berdampak pada perusahaan seperti kondisi makro ekonomi, perubahan kebijakan,perubahan politik dan juga kepekaan terhadap issue pada masyarakat.

Berkaitan dengan hasil yang akan diperoleh dari investasi, $50 \%$ responden setuju kalau hasil investasi membutuhkan waktu yang lama dan $50 \%$ responden tidak setuju. Investasi pada pasar modal akan bergantung pada tipe investor. Tipe trader dan investor sangat berbeda. Trader cenderung untuk mengejar capital gain sehingga kemungkinan untuk meningkatkan nilai investasi lebih cepat dibanding investor yang cenderung berpikir jangka panjang.

\subsection{Hubungan Tingkat Literasi Dengan Variabel Demografi}

Pada penelitian ini tingkat literasi didekati dengan tingkat pemahaman/pengetahuan responden tentang kelembagaan, produk dan perdagangan efek.Pertanyaan tentang kelembagaan berjumlah 10 pertanyaan. Jawaban benar mendapat skor satu dan jawaban salah skor nol. Rata rata skor responden terhadap pengetahuan tentangkelembagaan Pasar Modal sebelum pelatihan adalah $199 / 50=3,98$. Hal ini berarti rata rata responden menjawab benar kurang dari lima pertanyaan atau lebih dari 33,3\%. Kondisi ini menunjukan bahwa tingkat pengetahuan responden terhadap lembaga keuangan adalah tingkat sedang.

Setelah dua minggu responden menjawab kuestioner yang sama. Hasil setelah pelatihan sangat bervariatif. Terdapat tiga pertanyaan dijawab benar lebih dari $50 \%$ responden. Hal ini berarti belum ada peningkatan pengetahuan rata rata responden. Rata -rata skor responden terhadap pemahaman kelembagaan pasar modal sesudah pelatihan adalah $204 / 50=4,08$ berarti empat pertanyaan dijawab benar oleh responden. Pemahaman responden terhadap produk pasar modal sebelum dan sesudah pelatihan adalah 185/50 $=3,7$ dan 238/50 = 4,76 atau dengan kata lain tingkat pengetahuan rendah menuju sedang. Sementara tingkat pemahaman terhadap perdagangan efek sebelum dan sesuadah pelatihan adalah 228/50 = 4,56 dan $257 / 50=$ 5,14.Kondisi ini menunjukan bahwa tingkat pengetahuan responden terhadap lembaga keuangan adalah tingkat sedang.

Tingkat literasi Pasar Modal didekati dengan tingkat pengetahuan tentang kelembagaan, produk maupun perdagangan efek.Derajat keeratan hubungan antara tingkat pengetahuan responden tentang kelembagaan, produk maupun perdagangan efek dengan variabel demografi (gender, asal responden, asal program studi, semester, pendidikan orang tua dan pekerjaan orang tua) dapat dilihat dari besarnya koefisien Contingency.Nilai koefisien yang mendekati 0 berarti tingkat korelasinya lemah dan jika mendekati satu berarti korelasinya kuat. 
Tabel 2. Nilai Koefisien Congtingency

\begin{tabular}{|c|c|c|c|c|}
\hline \multirow{3}{*}{$\begin{array}{l}\text { Hubungan Tingkat Pengetahuan } \\
\text { tentang Kelembagaan Pasar Modal } \\
\text { dengan: }\end{array}$} & \multicolumn{4}{|c|}{ Koefisien Congtingency } \\
\hline & \multicolumn{2}{|c|}{ Sebelum Pelatihan } & \multicolumn{2}{|c|}{ Sesudah Pelatihan } \\
\hline & Value & $\begin{array}{l}\text { Asymp.Sig } \\
\text { (2 sided) }\end{array}$ & Value & $\begin{array}{l}\text { Asymp.Sig } \\
(2 \text { sided })\end{array}$ \\
\hline Gender & 0.039 & 0.781 & 0.208 & 0.132 \\
\hline Asal Mahasiswa & 0.061 & 0.665 & 0.019 & 0.895 \\
\hline Asal Program Studi & 0.347 & 0.078 & 0.553 & 0.021 \\
\hline Semester & 0.693 & 0.000 & 0.634 & 0.000 \\
\hline Pendidikan Orang Tua & 0.303 & 0.168 & 0.280 & 0.236 \\
\hline Pekerjaan Orang Tua & 0.076 & 0.990 & 0.148 & 0.236 \\
\hline $\begin{array}{l}\text { Hubungan Tingkat Pengetahuan } \\
\text { tentang Produk Pasar Modal } \\
\text { dengan: }\end{array}$ & & & & \\
\hline Gender & 0.132 & 0.643 & 0.196 & 0.368 \\
\hline Asal Mahasiswa & 0.081 & 0.849 & 0.066 & 0.895 \\
\hline Asal Program Studi & 0.465 & 0.032 & 0.388 & 0.182 \\
\hline Semester & 0.374 & 0.230 & 0.479 & 0.049 \\
\hline Pendidikan Orang Tua & 0.292 & 0.590 & 0.191 & 0.929 \\
\hline Pekerjaan Orang Tua & 0.371 & 0.434 & 0.304 & 0.749 \\
\hline $\begin{array}{l}\text { Hubungan Tingkat Pengetahuan } \\
\text { tentang Perdagangan Efek dengan : }\end{array}$ & & & & \\
\hline Gender & 0.158 & 0.528 & 0.265 & 0.151 \\
\hline Asal Mahasiswa & 0.010 & 0.998 & 0.092 & 0.808 \\
\hline Asal Program Studi & 0.399 & 0.148 & 0.224 & 0.854 \\
\hline Semester & 0.203 & 0.906 & 0.298 & 0.558 \\
\hline Pendidikan Orang Tua & 0.277 & 0.657 & 0.210 & 0.890 \\
\hline Pekerjaan Orang Tua & 0.357 & 0.506 & 0.423 & 0.207 \\
\hline
\end{tabular}

Sumber: Hasil Olah Data Tim Peneliti

Dari Tabel 2 tentang koefisien Congtingency tampak korelasi antara tingkat pengetahuan tentang kelembagaan dengan gender,asal responden,pekerjaan orang tua adalah sangat lemah. Sementara asal program studi dan pekerjaan orang tua berkorelasi lemah. Variabel semester berkorelasi sedang dengan tingkat pengetahuan kelembagan responden.

Hubungan tingkat pengetahuan tentang produk Pasar Modal dengan asal responden adaah lemah.Sementara korelasi antar tingkat pengetahuan tentang produk Pasar Modal dengan gender, pendidikan orang tua adalah lemah.Variabel semester dan asal program studi berkorelasi sedang dengan tingkat pengetahuan.Korelasi antara tingkat pengetahuan tentang perdagangan efek dengan asal mahasiswa adalah sangat lemah sedangkan korelasi dengan variabel lainnya lemah.

\subsection{Model Internalisasi Pendidikan Pasar Modal}

Literasi Pasar Modal didekati dari sisi pengetahuan yang berkaitan dengan kelembagaan pasar modal, produk pasar modal dan juga perdagangan efek.Hal ini penting dipahami oleh calon investor. Internasasi pasar modal dilakukan dengan cara mengadakan sekolah Pasar Modal bekerjasama dengan CMC Analis Keuangan dan PT Phintraco Semarang selaku perusahaan sekuritas.Sekolah Pasar Modal yang meliputi tiga materi pembahasan dan juga lomba Stock Lab yang dilakukan dalam satu hari memberikan hasil yang kurang optimal.Hal ini terlihat dari hasil pre test dan post test. Adapun hasilnya seperti ditunjukkan dalam Tabel 3. 
Tabel 3. Hasil Pre Test Dan Post Test

\begin{tabular}{ccc}
\hline Keterangan & Skor sebelum pelatihan & Skor sesudah pelatihan \\
\hline Kelembagaan & 3,98 & 4,08 \\
Produk & $3,74,76$ & \\
Perdagangan efek & $4,565.14$ & \\
\hline
\end{tabular}

Skor pemahaman/pengetahuan yang dimiliki responden dalam kategori rendah menuju sedang karena skor tertinggi adalah 10.Jika dikaitan antara tingkat pengetahuan kelembagaan, produk maupun perdagangan efek maka variabel program studi, semester responden maupun pendidikan orang tua punya peranan.

Hasil dari pertanyaan terbuka berkaitan dengan peningkatan pemahaman pasar modal adalah sebagai berikut:

a. Waktu pelatihan

Waktu pelatihan satu hari dirasakan masih kurang karena peserta pelatihan dari berbagai program studi. Ada peserta pengetahuan Pasar Modal yang telah memiliki bekal ilmu sebelumnya dan banyak yang belum memiliki.

b. Stocklab game

Pada umumnya peserta pelatihan tertarik dan antusias pada stocklab game. Dengan permainan tersebut mereka merasakan untuk berinvestasi perlu pengetahuan, perlu melihat situasi dan juga perlu memahami resiko.

c. Simulasi Perdagangan

Rata-rata peserta menginginkan adanya simulasi perdagangan dan bertransaksi secara real time.

d. Pendampingan

Beberapa mahasiswa menginginkan ada pendampingan dalam nabung saham.

Model Internalisasi Pasar Modal yang disarankan seperti ditunjukkan dalam Gambar 1.

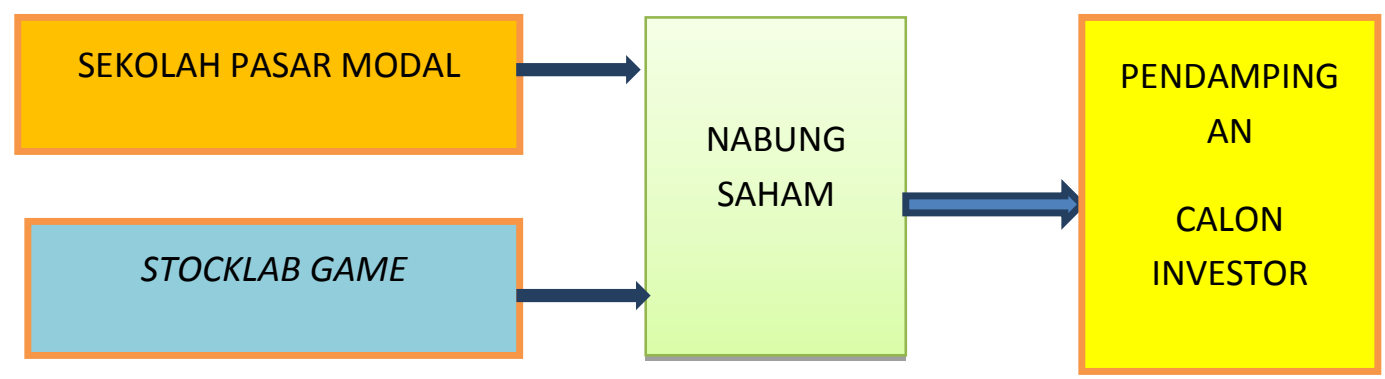

Gambar 1. Model Internalisasi Pasar Modal

\section{Kesimpulan}

Persepsi responden terhadap investasi pada industri Pasar Modal beragam responnya.Lebih dari $50 \%$ responden memiliki persepsi bahwa investasi pada pasar modal dapat dilakukan semua orang; tidak membutuhkan modal yang besar; investasi pada pasar modal tidak berbelit belit; bukan judi;tingkat resiko investasi pada pasar modal adalah high risk dan high return.

Tingkat literasi responden didekati dengan tingkat pemahaman/pengetahuan tentang kelembagan Pasar Modal, produk Pasar Modal dan Perdagangan Efek. Rata-rata skor responden terhadap pengetahuan kelembagaan Pasar Modal sebelum dan sesudah pelatihan adalah $199 / 50=$ 3,98 dan 4,08. Secara keseluruhan pemahaman responden terhadap produk pasar modal sebelum dan sesudah pelatihan adalah $185 / 50=3,7$ dan $238 / 50=4,76$. Rata-rata skor tingkat pengetahuan 
perdagangan efek sebelum dan sesuadah pelatihan adalah 228/50 =4,56 dan 257/50 = 5,14. Jadi secara umum tingkat pengetahuan mahasiswa terhadap Pasar Modal adalah rendah-sedang.

Hasil penelitian memperlihatkan bahwa tidak ada korelasi antara gender, asal responden, tingkat pengeluaran dengan tingkat literasi Pasar Modal.Sedangkan asal program studi dan semester berkaitan dengan tingkat literasi Pasar Modal. Sedangkan untuk endogenisasi Pasar Modal dimulai dengan sekolah Pasar Modal sehingga pengetahuan akan dimiliki oleh calon investor. Untuk peningkatan keterampilan maka tahapan berikut adalah nabung saham. Pada masa awal diperlukan pendampingan investor baru sampai investor dewasa (mampu bertransaksi sendiri).

\section{Saran}

Penelitian lebih lanjut tentang tipe investor dan perilaku investor mahasiswa sehingga akan diperoleh bentuk literasi pasar modal terhadap generasi muda.

\section{Ucapan Terima Kasih}

Penelitian ini didanai oleh DIPA Polines tahun 2017. Terima kasih kami ucapkan kepada Pusat Penelitian dan Pengabdian Masyarakat Polines sehingga penelitian ini dapat terselesaikan.

\section{Daftar Pustaka}

Atkinson, A., and Messy, F. (2012).Measuring Financial Literacy. OECD Publishing.

Bonte, W. A. (2012). Financial Literacy, Information Flows, and Caste Affiliation: Empirical Evidence from India. Journal of Banking \& Finance, 36, 3399-3414.

Gupta,Kamal dan Jatinder Kaur.(2014). A Study of Financial Literacy Among Micro Entrepreneurs in District Kangra. International Journal of Research in Business Management.Vol 2,Issue 2, hal .2347-4572.

Kehiaian, S. and Williams, A. 2012. Financial Literacy and Characteristics of Chapter 13 Debtors. International Journal of Business, Accounting, and Finance, 6(1),142-155.

Lusardi, A. and Mitchell, O. (2011). Financial Literacy around the World: An Overview, Discussion Paper. Netspar Discussion Papers.

Lusardi,Annamaria, Olivia S. Mitchell, and Vilsa Curto.(2010). Financial Literacy among the Young.The Journal of Consumer Affair Vo.44,No.2.

M.,Samy,Taufik H.,Huang R.,Nagar,A.K. (2012).Financial Literacy of Youth.Asensitivity Analysis of Determinant.International Journal of Economic Sciences and Applied Research (1) pp.55-70.

Mandell,Lewis, and Linda Schmid Klein.(2009).The Impact of Financial Literacy Education on Subsequent Financial Behavior. Association for Financial Counseling and Planning Education.

Remund,David L.(2010).Financial Literacy Explicated: The Case of Clearer Definition in an Increasingly Complex Economy.The Journal of Consumer Affairs.

Scheresberg,Carlo de Bassa.(2013).Financial Literacy and Behavior among Young Adults: Evidence and Implication. Advancing Education in Quantitative Literacy Vol 6 Issue 2.

Sekaran,Uma.2006.Metodologi Penelitian Untuk Bisnis.Salemba Empat.Jakarta.

Siregar,Evalisa.(2014).BEI:Masyarakat Beranggapan Pasar Modal Sebagai Judi.http://www.antaranews.com/berita/457285/bei-masyarakat-beranggapan-pasarmodal-sebagai-judidiunduh tanggal 24 Mei 2017.

$\underline{\text { www.ojk.go.id }}$ 